Anna Bartnik

Institute of American Studies and Polish Diaspora

Jagiellonian University, Kraków, Poland

\title{
The World Before Control: American Immigration
}

\section{Law and Policy During Colonial Times}

\begin{abstract}
In debates on American immigration law, it is possible to encounter the argument that there were no laws restricting newcomers' flow into America till the end of the $19^{\text {th }}$ century. An inaccurate understanding of American immigration policy sometimes leads to the opinion that prior to the beginning of the federal immigration power, there was no immigration policy at all in America. This article describes regulations enacted by the colonies and the states, as well as activities taken by them, to control the influx of newcomers. They tried to encourage immigrants to come to America while simultaneously controlling who was coming. The idea of successful control over immigrants coming to the North American continent was rooted in restrictive laws determining who was admissible. Paupers, criminals and those with contagious diseases were undesirable. Colonial and state authorities tried to stop their influx or, at least, to lessen the danger they posed. The main goal of the presented article is to analyze and present arguments proving or neglecting the assumption that there was a lack of an immigration policy during colonial times in America.
\end{abstract}

\section{A Nation of Immigrants}

America is a nation of immigrants - this statement is commonly used by authors of many books and articles that discuss immigration issues (Jacobson 1; DeSipio, de la Garza 45). Starting with President John Fitzgerald Kennedy's book, A Nation of Immigrants (Lee 26), this short phrase has appeared on the front covers of books so many times that no one can doubt what country it refers to. These words do not reveal any mystery, do not deliver any surprise or amazement, and do not even ask a question that scholars could try to answer by conducting proper research. The most interesting issue is: What makes the phrase so popular among immigration researchers, and why is the sentence so often mentioned? The reason lies beneath the simple meaning of these few words, linked together in a statement. It is a universal and timeless idea that makes this phrase always true. Irrespective of many different 
factors, such as historical periods, times of war or peace, the economy's ups and downs, etc., the truth has been always obvious - America was created by people on the move.

Immigration to America started more than four hundred years ago. The exact dates describing the beginning of immigration differ. Some scholars note (Bailey 27) that the first immigrants on American soil, meaning the continent, were conquistadors. Others say (Bodvarsson, Van den Berg 14) that we can start talking about immigrants coming to America from the day when the United States became a country. All researchers, however, stress the complicated nature of this issue. Most of them say that the most important first task is to define immigrants (Higham 6). A definition used for explaining who an immigrant is may exclude or include some groups of people living in America. Conventional wisdom states that an immigrant coming to America is a person who chooses that place as his destination. There are many categories of immigrants, based on the reason why they chose America as their new home. Among these categories, there are people looking for a job, escaping from persecution or joining their families. Irrespective of the specific reason for coming to the North American continent, they all had to make a decision to migrate, on their own. However, following that common idea, it is necessary to exclude from that category those who came to America on a different basis. Among them were the first settlers, who chose not America, but an empty, wild no man's land, as they believed at the time. Then, considering the comments mentioned above, we cannot call African slaves immigrants, since they were brought to America forcibly. They were not allowed to make their own decision to migrate, as nobody ever asked them to. And another group consists of Mexicans, living in a territory annexed by the United States after the war with Mexico in 1848 (Dinnerstein, Reimers 5). They did not move - the border moved, making them suddenly residents of the United States of America.

To include all groups of newcomers building the myth of a nation of immigrants, William Williams (Williams 19) suggested focusing on "the effects of the physical, social, and cultural series of acts involved in abandoning home and homeland, crossing the ocean, and settling in a new place amid strangers, then we might conclude that the impact of immigration is the quintessential American experience, establishing a pattern that is replicated in almost every aspect of American life."

\section{First Immigrants}

Immigration regulations appeared very quickly after the first waves of settlers' arrival. They tended to increase in number till the immigration law, considered as a set of comprehensive rules, was created. Although the idea of America has changed through the centuries, there has always been something that has made this land attractive to foreigners. The first immigrants, the pilgrims, idealized the new land as the Promised Land, a sacred asylum for those who were persecuted in their own countries (Delbanco, Heimert 39). Puritans, building the first colonies, were trying to create an ideal world. It quickly appeared to be impossible. Among settlers, as well as newcomers, there were those who did not share similar views. Puritans believed they were dangerous to the order they were building in their settlements, and tried 
to neutralize that danger. In 1637, the General Court of Massachusetts announced that no foreigner could be housed in any colony town or home without the permission of the colonial authorities (Lane 490). The situation became even more complicated when Quakers started their activity in the colonies. The Puritans of Massachusetts enacted laws (later repealed) aiming to lessen the so-called "Quaker threat" (Pestana 32). Quakers, already present in colonial America, experienced various acts of violence aiming to discourage them from practicing their beliefs.

Beginning in 1656, not only Massachusetts but also the rest of the New England colonies (the only exception being Rhode Island) decided to implement new laws preventing and securing them from Quakers. Colonial authorities even reached for the most severe restrictions. They forbade them entry to the colonies under penalty of death. In New England, there was an ordinance saying that a captain of a vessel with Quakers on board had to pay a fine (Jackson, nytimes.com). These regulations were important arguments in the discussion on American immigration law. When thinking about immigration control in America, these $17^{\text {th }}$-century provisions preceded early immigration laws enacted in the USA. However, scholars such as Michael C. LeMay, Alasdair Kean, Neil Campbell, Erika Lee and Judy Yung believe that till the end of the $19^{\text {th }}$ century, immigration flow to America was unrestricted (LeMay 1; Campbell, Kean 51; Lee, Yung 6). On the other hand, Anna O. Law argues "that assumption is based on historical amnesia of more than a century of U.S. history in which the colonies and then the states almost exclusively made and implemented immigration policy."

From many present day immigrants' point of view, American immigration during colonial times was a dream. Newcomers were not only welcomed, but also encouraged to come. The only exception were those who came into conflict with the law in their native countries. It didn't matter if they decided to come to America by themselves, escaping from serving jail sentences, or were sent there by their governments. Pioneers who had already settled American colonies were trying to stop these unwanted "neighbors" by enacting laws prohibiting their influx. The British Crown often overruled them, which created tension in the colonies. Sending convicts to colonies beyond the seas was a typical practice not only in England, but also in Spain and Portugal. The British were still sending criminals to the thirteen colonies before 1776, when the American War of Independence began (Page, Sonnenburg 462). Sending criminals to the colonies was a popular ruling among British courts. 36,000 convicts were sent to the colonies under the Transportation Act of 1717 (Woods 20). At that level of development, American settlers needed more laborers, especially for tobacco cultivation and the sugar industry. On their arrival to the colonies, criminals were sold by merchants and shippers to plantation owners for the duration of their sentence (Pfeffer 50).

One of the characteristic features in American immigration policy during the colonial period was a shared responsibility. It used to be an issue engaging two subjects. During colonial times, both the British Crown and colonial governments were responsible for the first immigration laws (Zolberg 24). Both of them were located on different stages of power. The Crown had conclusive and irrefutable legislative power and colonial governments enacted and enforced immigration laws within the empire framework. After the American Revolution, there was a time of states' "self-governing" in the immigration field. States were responsible for all issues 
connected with the constant flow of newcomers until the federal government of the United States decided to restrict immigration issues to its exclusive powers (DeSipio, de la Garza 46).

However, the overall attitude toward immigration in the colonial era was positive. Colonial communities needed laborers. Planters, increasing their land and crops, needed people to take care of tobacco, rice and corn. The laborers available in America were not enough. Till the end of the first half of the $17^{\text {th }}$ century, bringing people from England was not complicated, as the country had many internal problems and there were many who wanted to leave the isles. During the period of the English Civil War (1642-1651), a series of penal laws were passed against Roman Catholics, forcing them to leave the country. Because of the unstable political situation, the colonies were left alone with their labor shortage. They solved the problem on their own by encouraging newcomers to start a new life in America. The problem became more complicated after Oliver Cromwell's protectorate period, when Charles II reinstated the monarchy. During his reign, from 1661 to 1685, he opposed Englishmen's migration to the New World, arguing that it lessened the country (Dinnerstein, Reimers 9). Hence, the potential labor force, so badly needed in the colonies, was more heavily recruited in Europe.

Recruitment campaigns aimed to attract people to come to America by showing them different opportunities offered by colonial governments. The colonies were described as places of freedom. For example, William Penn (the founder of Pennsylvania) announced that Pennsylvania had given all males the right to vote, required no military service and had enacted a humane penal code (Bernard 49). To encourage potential newcomers to make a positive decision on migration, they were promised help with transportation, land purchase and other settlement arrangements. Professional advertisers were hired to convince potential immigrant laborers to choose America. Their role was important. However, a decision to migrate was very often based on less "professional" sources of information. Ordinary people also played an important role in shaping Europeans' minds with visions of America. Oral relations, letters, diaries and other forms of communicating news seemed to be more credible for potential migrants. They were delivered by people whom they trusted, such as relatives, friends or neighbors.

The need for a labor force was so urgent that colonial governments decided to implement additional solutions to bring more immigrants. These included rewards for recruiters who convinced the largest number of Europeans to migrate to America. They also subsidized the purchase of land, or, like in Virginia, practiced 'indentured servitude.' This became a particularly useful procedure in bringing newcomers to America.

Richard B. Marrin states that maybe as many as two thirds of all white immigrants to America's Middle Atlantic and Southland arrived as indentured servants (Marrin 1). The deal was simple. Immigrants were not supposed to bother about transportation to America because they were offered a free passage. They also did not have to worry about living conditions, as they were promised a years' provisions as well as a house, tools and a share of produced crops. In return, they bound themselves to a planter or a company for a period of years - usually from four to seven years, until their passage was paid back in the form of labor. They were promised to receive their freedom back after serving their time as indentured 
servants. Moreover, they often had an opportunity to hold the title to the land. That procedure was in use till the end of the American Revolution. Then, when it became more problematic because exploited servants began to rebel, they were replaced by slaves and an increasing number of labor immigrants coming from all over the world.

During the colonial period, there was also another system in use, even more beneficial for planters. It was used in Virginia and Maryland, and was called a headright system (Walton, Rockoff 31). For each white laborer that was brought to America from England by plantation owners, they were given 50 acres of new land. Thanks to these regulations, they benefited twofold - first, by increasing their land holdings, and secondly by using indentured servants' work (Kulikoff 109).

By 1700, nearly all colonies were using some or all of these ways to attract immigrants and increase their flow to America. Availability of work was one of the main incentives that drew people to the colonies. Religion became an additional determinant. Some communities advertised themselves as extremely tolerant for all Christian people. Others preferred people of one denomination. Time proved that the idea of religious tolerance, seen not only as a key to attract immigrants, was the right one. As William Bernard (Bernard 51) stated, "religious conformity itself declined throughout the $18^{\text {th }}$ century. Without coercive authority, secure leadership, and state sanctions, religion became a matter of choice with little formal relevance to civil status, and religious tests for entry into any of the colonies soon fell into disuse."

\section{The Growth of Restrictions}

The $18^{\text {th }}$ century brought new immigrants to America. The flow was stimulated by changes in hitherto regulations. The headright system was abandoned, and the land became more accessible for all newcomers. The problem that did not change was a divergent vision of immigration to the colonies, expressed by the British Crown and by colonial governments.

With the growing flow of immigrants to America, settlers became more prudent. Their prior experience with criminals and outlaws coming to the colonies made them think positively about the need for proper regulations. Newcomers' health became one of the first issues to consider. People migrating to America were bringing not only valuable work power, but also diseases and disabilities. Such immigrants were seen as burdensome and a threat to colonial communities, hence unwelcome. However, exclusions on the grounds of contagious diseases were added to federal immigration law, not before the end of the $19^{\text {th }}$ century (Neuman 1859). For a long time, immigration issues were considered the states' problem and they were granted responsibility for taking care of public health. During the $18^{\text {th }}$ century (and for the most of the $19^{\text {th }}$ century), regulations were enacted which introduced the mechanism of quarantine. It had been in use in colonial America since 1663, when New York restricted entrance to the city to try to avoid an outbreak of smallpox (Lazaretto Quarantine Station; ushistory.org). Soon, quarantine stations, not only in New York, were built. Passengers and crew were isolated in order to observe whether asymptomatic persons had become infected. Immigrants who were already sick were kept there till their death or recovery. These procedures generated costs and some governments 
decided to use taxes to collect money for quarantine needs. However, it was soon invalidated by the Supreme Court on commerce clause grounds. Quarantine laws were significant in the history of American immigration. They introduced one of the first barriers in immigrants' free flow to the colonies. Moreover, the enactment of additional regulations securing colonies against diseases, such as fees that carriers had to pay, or the forbidding of any contact with "infected" territories, made the cost of the journey to America higher. Unfortunately, many of those regulations appeared to be dead letters, and the number of immigrants coming to America was almost beyond control. For this reason, the colonies had to implement new regulations to gain control over newcomers.

Pennsylvania was one of the first colonies trying to control the problem. In 1727, the colonial government announced the Memorial Against Non-English Immigration. It was Pennsylvanians' response to British indifference. After experiencing an arrival of 1,300 Germans in a single month, Pennsylvanians appealed to the Crown for aid, but it did not come. Finally, they decided to implement their own program to control immigrants. Living with fear that "the newcomers, 'Ignorant of our Language \& Laws,' would create foreign enclaves, squat on lands they did not intend to purchase, and stir up the Indians by their presence on the frontier" (Baseler 72), the Provincial Council ordered new regulations. According to these, the shipmaster's list of passengers had to be more detailed and provide information on passengers' names, occupations, places of residence and reasons for emigrating. Each immigrant was also required to sign a declaration of allegiance. In 1729, an additional requirement was established. A tax of forty schillings was laid on each non-English immigrant. It became the first case of using a head tax in America as a restrictive measure in immigration policy.

\section{Summary}

Thomas Hammar notes: “There is an obvious relation between a country's immigration policy and its terminology. (...) The technical language used in each country is adjusted so that it best describes and explains the country's policy. Terminology also influences the way in which immigration policy is conceived and understood in each country (...)" (Hammar 12).

Nowadays, scholars are divided in their opinions. Some of them note that it is necessary to separate two basic issues introduced as "immigration law and policy" and "immigrant law and policy." The first describes any regulation connected with entering or leaving a state's territory. The second refers to the treatment of immigrants already present in a state. Such distinction can be useful while talking about federal activity in the immigration field and state-based services. However, $19^{\text {th }}$-century immigration policy as well as colonial immigration regulations were parts of both immigration and immigrant policy.

Reed Ueda proposes using the term "immigration laws," as it has a broader and more complex meaning. It refers not only to the process of immigration itself, but immigrants as well (Ueda 7). An immigrant, being a subject of law, is also a member of a receiving community, society, country, etc. He interacts in different fields, both with other members of that community and the state's government. 
Immigration policy is strongly connected with history, but also with the contemporary situation of a receiving state. Many different internal and external determinants shape it. During the colonial period in American history, laws relating to a newcomer's presence reflected the needs and fears of those days. Early settlers did not have to restrict immigration, as they did not consider newcomers as rivals. There were plenty of possibilities for everyone and there was no need to fight for land or a job, etc. Moreover, the fast development of the colonial economy forced settlers to seek an immigrant labor force. This situation made governments of the time regulate problems connected with hiring immigrants, settling them down on new land, and determining what conditions newcomers needed to fulfill to become welcome. Prejudice was usually met on religious grounds, and communities that did not want to receive people of different denominations enacted proper regulations. But building barriers and excluding those who wanted to come to America was not in the early colonial nature. When the number of immigrants increased, however, colonial communities started enacting laws protecting them and their neighborhoods from threats generated by newcomers. Some of these laws became so strongly rooted in American minds that they survived in American immigration policy, even after the revolution, when the United States was born. One of them was the Plantation Act, enacted by the British Parliament in 1740, which became the model for the future U.S. naturalization laws. After seven years of residence, paying a small fee and swearing allegiance to the king of England, almost each communicant of any Protestant sect could become a citizen (Carr 130). Kanstroom also points out (Kanstroom 25) that there were special provisions that allowed some Quakers and Jews to naturalize, if they satisfied the residence requirement. No such exception was made for Roman Catholics.

Even contemporary deportation procedure is also traced from colonial times. At the beginning of that period in American history, Catholics and Quakers were oppressed. For practicing their religion they were punished with exclusion or banishment by colonial authorities. Colonial practices also set another template that eventually became a contemporary solution enacted in American immigration law. Many colonial regulations focused on people whose presence in America was not desired. Besides religiously motivated exclusions, there were also laws aimed to control or stop poor immigrants from entering. The colonies implemented different solutions. Massachusetts prohibited entry of poor immigrants, New York required a security bond for passengers and Pennsylvania introduced a head tax on all immigrants. Today, there is also a rule in American immigration law that there must be someone responsible for immigrants who might become a public charge (Law 2011).

\section{References}

Bailey, Rayna. Immigration and Migration. New York: Infobase Publishing, 2009.

Baseler, Marilyn C. "Asylum for Mankind": America, 1607-1800. Ithaca, N.Y.: Cornell University Press, 1998.

Bernard, William S. "Immigration: History of U.S. Policy." The Immigration Reader. America in a Multidisciplinary Perspective. Ed. David Jacobson. Malden, Mass.: Blackwell Publishers Ltd., 1998. 
Bodvarsson, Örn B., and Hendrik Van den Berg. The Economics of Immigration: Theory and Policy. New York: Springer Science \& Business Media, 2013.

Campbell, Neil, and Alasdair Kean. American Cultural Studies: An Introduction to American Studies. London: Psychology Press, 1997.

Carr, Revell J. Seeds of Discontent: The Deep Roots of the American Revolution, 1650-1750. New York: Bloomsbury Publishing USA, 2010.

Delbanco, Andrew, and Alan Heimert. The Puritans in America: a Narrative Anthology. Cambridge: Harvard University Press, 2009.

DeSipio, Louis, and Rodolfo O. de la Garza. U.S. Immigrant and Immigration Policies in the Twenty-First Century: Making Americans, Remaking America. Boulder: Westview Press, 2015.

Dinnerstein, Leonard, and David M. Reimers. Ethnic Americans: A History of Immigration. New York: Columbia University Press, 2009.

Hammar, Thomas. European Immigration Policy. A Comparative Study. New York: Cambridge University Press, 1985.

Higham, John. Send These To Me: Immigrants In Urban America. Baltimore: John Hopkins University Press, 1984.

Jackson, Kenneth T. "A Colony With a Conscience." The New York Times, 27 December 2007. Web. 1 August 2013. http://www.nytimes.com/2007/12/27/opinion/27jackson. html?_r=2\&ex=1199422800\&en=cfbcbbb90ef4c23d\&ei=5070\&emc=eta1\&.

Jacobson, David. "Introduction: An American Journey." The Immigration Reader. America in a Multidisciplinary Perspective. Ed. David Jacobson. Malden, Mass.: Blackwell Publishers Ltd., 1998.

Kanstroom, Dan. Deportation Nation: Outsiders in American History. Cambridge, Mass.: Harvard University Press, 2007.

Kulikoff, Allan. From British Peasants to Colonial American Farmers. Chapel Hill: University of North Carolina Press, 2000.

Lane, Brittney M. Testing the Borders: The Boundaries of State and Local Power to Regulate Illegal Immigration. 39 Pepp. L. Rev. 2, 2013. Web. 24 February 2015. http:/ / digitalcommons.pepper dine.edu/cgi/viewcontent.cgi?article=1364\&context=plr.

Law, Anna O. Colonial and State Immigration Policy and Immigration Federalism, 1700s-1892. 10 August 2011. APSA 2011 Annual Meeting Paper. Web. http:/ / ssrn.com/abstract=1901142.

Lazaretto Quarantine Station. Independence Hall Association. Web. 8 September 2013. http:/ / www.ushistory.org/laz/history/index.htm.

Lee, Erika. "A Nation Of Immigrants and a Gatekeeping Nation: American Immigration Law and Policy." A Companion to American Immigration. Ed. Reed Ueda. Malden, Mass.: John Wiley \& Sons, 2011.

Lee, Erika, and Judy Yung. Angel Island: Immigrant Gateway to America. Oxford: Oxford University Press, 2010.

LeMay, Michael C. Transforming America: Perspectives on U.S. Immigration. Vol. 1. Santa Barbara: ABC-CLIO, 2013.

Marrin, Richard B. Runaways of Colonial New Jersey: Indentured Servants, Slaves, Deserters, and Prisoners, 1720-1781. Westminster: Heritage Books, 2007.

Neuman, Gerald L. "The Lost Century of American Immigration Law (1776-1875)." Columbia Law Review 93: 1993 (8). Web. 4 August 2013. http://www.jstor.org/stable/1123006.

Page, Melvin E., and Penny M. Sonnenburg. Colonialism: An International, Social, Cultural, and Political Encyclopedia. A-M. Vol. 1. Santa Barbara: ABC-CLIO, 2003.

Pestana, Carla Gardina. Quakers and Baptists In Colonial Massachusetts. Cambridge: Cambridge University Press, 2004.

Pfeffer, Jeremy I. From One End of the Earth to the Other: The London Bet Din, 1805-1855, and the Jewish Convicts Transported to Australia. Brighton: Sussex Academic Press, 2009.

Ueda, Reed. A Companion to American Immigration. Chichester: John Wiley \& Sons, 2011. 
Walton, Gary M., and Hugh Rockoff. History of the American Economy. Mason, South-Western: Cengage Learning, 2012.

Williams, William H. A. "Immigration as a Pattern In American Culture." The Immigration Reader. America in a Multidisciplinary Perspective. Ed. David Jacobson. Malden, Mass.: Blackwell Publishers Ltd., 1998.

Woods, Gregory D. A History of Criminal Law in New South Wales: The Colonial Period, 1788-1900. Annandale: Federation Press, 2002.

Zolberg, Aristide R. A Nation by Design: Immigration Policy in the Fashioning of America. Cambridge: Harvard University Press, 2009. 